\title{
ANALISIS KINERJA KEUANGAN PT. BANK SINARMAS Tbk, UNIT USAHA SYARIAH
}

\author{
Suwarni, Karona Cahya Susena, Wika Gusti Halimah \\ Fakultas Ekonomi Universitas Dehasen Bengkulu \\ karona_cs@yahoo.co.uk
}

\begin{abstract}
ABSTRAK
Suwarni, Karona Cahya Susena, Wika Gusti Halimah; Tujuan dari penelitian ini adalah untuk mengetahui dan mengukur tingkat kinerja keuangan PT. Bank Sinarmas Tbk, Unit Usaha Syariah Tahun 2014-2016. Bisnis syariah dengan rasio keuangan adalah rasio Likuiditas, rasio Solvabilitas, dan Rentabilitas.

Hasil penelitian ini menunjukkan bahwa Cast Ratio dari tahun 2014 sampai 2016 adalah 47,57\%, 219,70\% dan 312,21\%. Dari Loan Deposito Ratio (LDR) dari tahun 2014 sampai 2016 adalah 81,22\%, 72,73\% dan 17,06\%. Dari perspektif Capital Adequacy Ratio, pada tahun 2014 sampai 2016 nilainya 125,06\%, 362,18\% dan 2,285\%, sedangkan dari perspektif Debt to Equity, pada tahun 2014 sampai 2016 nilainya 84,27\%, 29,84\% dan 12,88\%. Dengan menggunakan BOPO pada tahun 2014 sampai 2016 nilainya 65,83\%, 109,21\% dan 155,49\%. Dari perspektif Return on Assets, pada tahun 2014 sampai 2016 nilainya adalah 1,31\%, 0,10\% dan 1,64\%. Sedangkan dari Return on Equity pada tahun 2014 sampai 2016 nilai adalah $2,41 \%, 0,26 \%$, dan $1,85 \%$.
\end{abstract}

\begin{abstract}
Suwarni, Karona Cahya Susena, Wika Gusti Halimah; The purpose of this study is to determine and measure the level of financial performance of PT. Bank Sinarmas Tbk, Sharia Business Unit Year 2014-2016. Sharia business with financial ratios are Liquidity ratio, Solvency ratio, and Profitability.

The result of this study shows that Cast Ratio from 2014 until 2016 is 47,57\%, 219,70\% and 312,21\%. From Loan Deposito Ratio (LDR) from 2014 until 2016 are 81,22\%, 72,73\% and 17,06\%. From Capital Adequacy Ratio perspective, in 2014 until 2016 the values are 125,06\%, 362,18\% and 2.285\%, meanwhile from Debt to Equity perspective, in 2014 until 2016 the values are 84,27\%, 29,84\% and 12,88\%. By using BOPO in 2014 until 2016 the values are 65,83\%, 109,21\% and 155,49\%. From Return on Assets perspective, in 2014 until 2016 the values are 1,31\%, 0,10\% and1,64\%. Meanwhile from the Return on Equity in 2014 until 2016 values are $2,41 \%, 0,26 \%$, and $1,85 \%$.
\end{abstract}

Key Words: Liquidity Financial Report ratio, Solvability, Profitability, Financial Performance.

\section{LATAR BELAKANG}

Dunia perbankan di Indonesia memasuki masa persaingan yang sangat kompetitif, hal ini disebabkan banyaknya bank beroperasi di Indonesia baik yang beroperasi secara lokal, maupun yang beroperasi berskala internasional. Perkembangan dunia perbankan yang sangat pesat serta tingkat kompleksitas usaha perbankan yang tinggi dapat berpengaruh terhadap kinerja keuangan-keuangan suatu bank. Lemahnya kondisi internal bank seperti manajemen yang kurang kelompok atau group usaha sendiri serta modal yang tidak dapat mengcover bank terhadap resiko-resiko yang dihadapi oleh bank tersebut dapat menyebabkan kinerja bank menurun.

Bank merupakan industri yang dalam kegiatan usahanya mengandalkan kepercayaan masyarakat. Bank dianggap sebagai tempat kepercayaan nasabah untuk mengelola dananya. Bank dengan manajemen yang baik harus bisa menjaga kepercayaan nasabah dalam penyimpan dananya. Salah satu pemeliharaan kesehatan bank dilakukan dengan tetap menjaga likuiditas sehingga bank dapat memenuhi kewajibannya dan menjaga kinerjanya agar bank selalu memperoleh kepercayaan dari masyarakat. Kepercayaan masyarakat terhadap bank akan terwujud apabila bank mampu meningkatkan kinerjanya secara optimal.

Suatu bank dapat menjalankan seluruh kegiatannya dengan baik, tindakan yang perlu dilakukan adalah perencanaan, pengoperasian, pengendalian, dan pengawasan. Proses aliran keuangan secara terus menerus dan mencatatnya dalam laporan keuangan yang terdiri dari neraca dan perhitungan laba-rugi. Laporan keuangan bagi suatu perusahaan hanyalah suatu alat penguji dari pekerjaan bagian pembukuan akan tetapi selanjutnya laporan keuangan tidak hanya sebagai alat penguji saja tetapi juga sebagai dasar untuk dapat menentukan atau menilai posisi atau kondisi keuangan perusahaan tersebut. 
Dengan analisa rasio keuangan ini dapat diketahui kekuatan dan kelemahan perusahaan pada bidang keuangan. PT. Bank Sinarmas Tbk, Unit Usaha Syariah sebagai salah satu bank milik swasta yang terus berkembang di provinsi bengkulu. PT. Bank Sinarmas Unit Usaha Syariah harus menaruh perhatian penting pada penciptaan dan pemeliharaan keunggulan bersaing melalui penyampaian produk dan pelayanan yang lebih baik pada nasabah. Untuk dapat menjamin suatu organisasi berlangsung dengan baik, maka organisasi perlu mengadakan evaluasi terhadap kinerjanya, salah satu evaluasi tersebut adalah kinerja keuangan.

\section{LANDASAN TEORI}

\section{Laporan Keuangan Bank}

Laporan keuangan yang telah disusun berdasarkan data yang relevan, sertadilakukan dengan prosedur akuntansi dan penilaian yang benar, akan terlihat kondisikeuangan perusahaan yang sesungguhnya. Kondisi keuangan seperti berapa jumlahaset, utang, ekuitas dalam neraca yang dimiliki, pendapatan yang diterima danjumlah beban yang dikeluarkan selama periode tertentu sehingga dapat diketahuibagaimana hasil usaha (laba atau rugi) yang diperoleh selama periode tertentu dalamlaporan laba rugi yang telah disusun. Untuk mengetahui kondisi keuangan tersebutadalah dengan analisis atau analisa laporan keuangan sehingga laporan keuanganlebih mudah dipahami dan dimengerti serta dapat memberikan informasi tentangkelemahan dan kekuatan yang dimiliki perusahaan.

Menurut Subramanyam (2014:4) Analisis laporan keuangan (financial statement analysis) adalah aplikasi dari alatdan teknik analitis untuk laporan keuangan bertujuan umum dan data-data yangberkaitan untuk menghasilkan estimasi dan kesimpulan yang bermanfaat dalam analisis bisnis. Analisis laporan keuangan mengurangi ketergantungan padafirasat, tebakan, dan intuisi dalam pengambilan keputusan, serta mengurangiketidakpastian analisis bisnis.

setiap jenis usaha atau perusahaan mempunyai catatan laporan keuangan yang berguna untuk menguji dan mengetahui serta menilai kondisi dan posisi keuangan perusahaan tersebut. menunjukkan kondisi keuangan perusahaan pada saat ini atau dalam suatu periode tertentu (Kasmir, 2012:7). laporan keuangan merupakan ringkasan dari suatu proses pencatatan, serta merupakan ringkasan dari transaksitransaksi keuangan itu disusun dengan maksud untuk menyediakan informasi keuagan mengenai suatu perusahaan kepada pihak-pihak yang berkepentingan sebagai bahan pertimbangan dalam pengambilan keputusan-keputusan ekonomi. Oleh karnaitu laporankeuangan merupakan sumber utama untuk berbagai pihak yang membutuhkan.

Menurut Ikatan Akuntansi Indonesia dalam bukunya yang berjudul "Standar Akuntansi Keuangan" adalah Laporan keuangan yang lengkap biasanya meliputi neraca, laporan laba rugi, laporan perubahan posisi keuangan (yang dapat disajikan dalam berbagai cara, misalnya: laporan arus kas dan laporan arus dana), catatan dan laporan lain, serta informasi tambahan yang berkaitan dengan laporan tersebut.

Laporan keuangan disusun secara periode, Periode akuntansi yang lazim digunakan adalah tahunan, triwulan atau kuartal, dan bulanan. Setiap laporan keuangan yang dibuat mempunyai tujuan tertentu, Secara umum laporan keuangan suatu perusahaan, baik pada saat tertentu maupun pada periode tertentu. Tujuan pembuatan atau penyusunan laporan keuangan menurut Kasmir (2012:10) Adalah:

1. Memberikan informasi tentang jenis dan jumlah aktiva (harta) yang dimiliki perusahaan pada saat ini

2. Memberikan informasi tentang jenis dan jumlah kewajiban dan modal yang dimiliki perusahaan pada saat ini

3. Memberikan informasi tentang jenis dan jumlah pendapatan yang diperoleh pada suatu periode tertentu

4. Memberikan informasi tentang jumlah biaya dan jenis biaya yang dikeluarkan perusahaan dalam suatu periode tertentu; Memberikan informasi tentang perubahan-perubahan yang terjadi terhadap aktiva, pasiva, dan modal perusahaan

5. Memberikan informasi tentang kinerja manajemen perusahaan dalam suatu periode;

6. Memberikan informasi tentang catatan-catatan atas laporan keuangan;

7. Informasi keuangan lainnya.

Berdasarkan tujuan di atas, dengan disusunnya laporan keuangan suatu perusahaan akan dapat diketahui kondisi keuangan perusahaan secara menyeluruh. Laporan keuangan dasar bagi upaya analisis tentang suatu usaha, sehingga harus mengerti ati dari laporan keuangan. Arti dari laporan keuangan yaitu keseluruhan aktifitas-aktifitas yang bersangkutan dengan usaha-usaha untuk mendapatkan dana yang diperlukan dan biaya minimal dengan syarat-syarat yang paling menguntungkan serta usaha-usaha untuk 
menggambarkan dana tersebut seefisien mungkin. menggunakan informasi keuangan untuk menilai kinerja perusahaan yang tercermin dalam laporan keuangan dan hasil operasi perusahaan yang tercemin dalam laporan keuangan perusahaan pada hakekatnya merupakan hasil akhir dari kegiatan akuntansi perusahaan yang bersangkuta. Informasi tentang kondisi keuangan dan hasil operasi perusahaan sangat berguna bagi berbagai pihak.

Laporan bank membutuhkan informasi yang dapat dipahami, relevan, andal dan dapat dibandingkan dengan mengevaluasi posisi keuangan dan kinerja bank serta berguna dalam pengambilan keputusan ekonomi. pengguna juga membutuhkan informasi yang tidak tersedia untuk publik. Meskipun bankmerupakan objek pengawasan bank kewenangan pngaturan untuk tidak menyediakan informasi tertentu bagi masyarakat, tetapi dibutuhkan pengungkapan yang menyeluruh dan memadai agar laporan keuangan bank sesuai dengan kebutuhan pengguna, dalam batasan yang layak untuk dipenuhi oleh manajemen.

Menurut ikatan akuntan indonesia (2009:5-8) laporan keuangan yang dapat berguna bagi pemakai informasi bahwa harus terdapat 4 karakteristik kualitatif pokok yaitu dapat dipahami, relevan, keandalan, dan dapat di bandingkan.

1. dapat dipahami, informasi keuangan dapat dipahami adalah informasi yang disajikan dalam bentuk dan bahasa teknis yang sesuai dengan tingkat pengertian penggunaannya.

2. Relevan, informasi keuangan harus berpautan dengan tujuan pemanfaatannya.

3. Andal, agar bermanfaat informasi juga harus andal. Informasi yang memiliki kualitas andal jika bebas dari pengertian yang menyesatkan dan kesalahan yang material, dan dapat diandalakan pemakaiannya sebagai penyajian yang tulus atau jujur dari yang seharusnya disajikan atau yang sewajarnya diharapkan dapat disajikan.

4. Dapat diperbandingkan, informasi akuntan harus dapat diperbandingkan dengan informasi akuntansi periode sebelumnya pada perusahaan yang sama, atau dengan perusahaan yang sejenis lainnya pada periode waku yang sama maka:

1) Laporan keuangan disajikan dalam format yang sama,

2) Isi laporan keuangan adalah identik,

3) Prinsip-prinsip auntansi yang dianut tidak berubah, kalaupun berubah maka dampak perubahannya terhadap laba rugi periode sekarang harus diungkapkan,

4) Perubahan dalam kondisi yang mendasari harus transaksi diungkapkan.

\section{Jenis-jenis laporan keuangan}

Menurut Kasmir (2012:9), secara umum ada lima jenis laporan keuangan yang biasa disusun, yaitu:

1. Balance Sheet (Neraca)

Balance sheet (neraca) merupakan laporan yang menunjukkan posisi keuangan perusahaan pada tangga tertentu. Arti dari posisi keuangan dimaksudkan adalah posisi jumlah dan jenis aktivas (harta ) dan passiva (kewajiban dan ekuitas) suatu perusahaan.

2. Income Statement (Laporan Laba Rugi)

Income statement (laporan laba rugi) merupakan laporan keuangan yang menggambarkan hasil usaha perusahaan dalam suatu periode tertentu. Dalam laporan laba rugi ini tergambar jumlah pendapatan dan sumber-sumber pendapatan yang diperoleh. Kemudian juga tergambar jumlah biaya dan jenisjenis yang dikeluarkan selama periode tertentu. Adapun unsur-unsur pendapatan yang diperoleh dan beban yang dikeluarkan sebagai berikut:
a) Pendapatan bunga
b) Beban bunga
c) Pendapatan komisi
d) Beban provisi dan komisi
e) Keuntungan atau kerugian penjual efek
f) Keuntungan dan kerugian investasi efek
g) Keuntungan dan kerugian transaksi valuta asing
h) Pendapatan deviden
i) Pendapatan operasional lainnya
j) Beban penyisihan kerugian kredit dan asset produktif lainnya
k) Beban administrasi umum
l) Beban opersional lain. 
Nilai bersih bunga merupakan selisih antar pendapatan bunga dan beban bunga. Manajemen dianjurkan mengungkapkan rata-rata nilai aset yang menghasilkan bunga, dan rata-rata nilai kewajiban yang berbunga dalam periode yang bersangkutan.

3. Laporan Perubahan Modal

Laporan perubahan modal merupakan laporan yang berisi jumlah dan jenis modal yang dimiliki pada saat ini. Kemudian, laporan ini juga menjelaskan perubahan modal dan sebab-sebab terjadinya perubahan modal di perusahaan.

4. Laporan Arus Kas

Laporan arus kas merupakan laporan yang menunjukkan arus kas masuk dan kas keluar di perusahaan. Arus kas masuk berupa pendapatan atau pinjaman dari pihak lain, sedangkan arus kas keluar merupakan biaya-biaya yang telah dikeluarkan perusahaan. Baik arus kas masuk maupun arus kas keluar dibuat untuk periode tertentu.

Kas dan setara kas terdiri atas:

a) Kas

b) Giro pada bank indonesia

c) Giro pada bank lain.

Meningat bank mempunyai likuiditas yang sangat ketat jika dibandingkan dengan perusahaan umumnya maka penempatan yang segera akan jatuh tempo dalam waktu tiga bulan atau kurang dari tanggal perolehannya tidak termasuk dalam perhitungan ini.

5. Laporan Catatan Atas Laporan Keuangan

Laporan catatan atas laporan keuangan merupakan laporan yang dibuat berkaitan dengan laporan keuangan yang disajikan. Laporan ini memberikan infomasi tentang penjelasan atas laporan keuangan yang ada sehingga menjadi jelas sebab penyebabnya. Tujuannya adalah agar pengguna laporan keuangan dapat memahami jelas data yang disajikan.

\section{Analisis Rasio Keuangan Untuk Mengukur Kinerja Keuangan}

Kinerja keuangan adalah penentuan secara periodik tampilan keuangan berdasarkan sasaran, standar dan kinerja yang telah ditetapkan sebelumnya. Mengukur kinerja keuangan menggunakan analisis keuangan karena analisis keuangan melibatkan penilaian terhadap keuangan di masa yang akan datang dan untuk menentukan keunggulan suatu kinerja.

Menurut fahmi (2011:239), kinerja keuangan adalah: "suatu analisis yang dilakukan untuk melihat sejauh mana perusahaan telah melaksanakan keuangan secara baik dan benar".

Adanya informasi yang benar dan pemahaman mengenai kinerja bank maka diharapkan kepercayaan masyarakat terhadap perbankan semakin meningkat. Perhitungan yang dilakukan dengan menggunakan umum, yaitu dengan menggunakan analisis rasio keuangan. Membandingkan nilai rasio keuangan yang diperoleh dari tahun-tahun merupakan langkah berikutnya. Langkah ini diperlu dilakukan untuk mengetahui kondisi hasil hasil perhitungan tersebut apakah baik atau kurang baik.

Menurut Kasmir (2012:104), rasio keuangan merupakan kegiatan membandingkan angka-angka yang ada dalam laporan keuangan dengan cara membagi satu angka dengan angka lainnya. Berdasarkan pendapat para ahli diatas dapat ditarik kesimpulan bahwa rasio keuangan adalah cara membandingkan angka yang satu dengan angka lainnya dalam suatu laporan keuangan..

Perusahaan yang mampu memenuhi kewajiban keuangannya tepat pada waktu berarti perusahaan tersebut dalam keadaan "likuid", dan perusahaan dikatakan mampu memenuhi kewajiban keangan tepat pada waktunya apabila perusahaan tersebut mempunyai alat pembayaran ataupun aktiva lancar yang lebih besar dari pada hutang lancarnya atau hutang jangka pendek. Sebaliknya kalau perusahaa tidak dapat memenuhi kewajiban keuangannya pada saat ditagih berarti perusahaan tersebut dalam keadaan "illikuid".

Suatu perusahaan dikatakan"solvabel" apabila perusahaan tersebut mempunyai aktiva atau kekayaan yang cukup untuk membayar semua hutang-hutangnya, sebaliknya apabila aktiva tidak cukup atau lebih kecil daripada hutangnya berarti perusahaan tersebut dalam keadaan "insolvabel".

Rentabilitas suau perusahaan diukur dengan kesuksesan perusahaan menggunakan aktivanya secara produktif, dengan demikian rentabilitas suatu perusahaan dapat diketahui dengan membandingkan antara laba yang diperoleh dalam suatu periode dengan jumlah aktiva atau jumlah modal perusahaan tersebut.

Untuk mengukur kinerja keuangan perusahaan dapat dilakukan menggunakan analisis laporan keuangan. Adapun analisis laporan keuangan didasari oleh rasio-rasio keuangan (Bank Indonesia, 2013:14), sebagai berikut: 


\section{Rasio Likuiditas}

Suatu bank dikatakan liquid apabila bank yang bersangkutan dapat memenuhi kewajiban utangutangnya, dapat membayar kembali semua depositonya, serta dapat memenuhi permintaan kredit yang diajukan tanpa terjadi penangguhan. Oleh karena itu, bank dapat dikatakan liquid apabila: 1) bank tersebut memiliki cash assets sebesar kebutuhan yang digunakan untuk memenuhi likuiditasnya, 2) bank tersebut memiliki cash assets yang lebih kecil dari kebutuhan likuiditasnya, tetapi mempunyai aset atau aktiva lainnya (misal surat berharga) yang dapat dicairkan sewaktu-waktu tanpa mengalami penurunan nilai pasarnya, dan 3) bank tersebut mempunyai kemampuan untuk menciptakan cash asset baru melalui berbagai bentuk hutang (Kasmir, 2009).

Dalam rasio likuiditas, rasio yang dapat diukur antara lain: Cash Ratio dan Loan Deposit Ratio (LDR).

1) Cash Ratio/ Quick Ratio, yaitu Rasio ini untuk mengetahui kemampuan bank dalam membayar ke menggunakan alat likud dimilikinya.

Rumus:

$$
\mathrm{CR}=\frac{\text { Alat likuid } \times 100 \%}{\text { Hutang lancar }}
$$

Alat likuid adalah uang kas di bank dan rekening giro yang disimpan dibank indonesia.

2) Loan to Deposit Ratio (LDR), adalah kemampuan bank dalam membayar kembali penarikankewajiban kepada para nasabahyang telah menanamkan da yang dilakukan nasabah dengan mengandalkan kredit yang diberikanpara debiturnya. Rasio ini adalah antara seluruh jumlah kredit yang diberikan bank dengan dana yang direima oleh bank. Semakin tinggi rasionya semakin tinggi tingkat likuiditasnya.

Rumus: $\mathrm{LDR}=\frac{\text { Total Kredit } \times 100 \%}{\text { Total Deposito }+ \text { Modal }}$

\section{Rasio Solvabilitas}

Analisis rasio permodalan sering disebut juga rasio solvabilitas. Analisis solvabilitas digunakan untuk mengukur kemampuan bank untuk memenuhi kewajiban-kewajiban jika terjadi likuidasi bank. Rasio solvabiitas dapat diukur dengan perhitungan capital adequacy ratio (CAR) dan Debt To Equity Ratio (DTE).

a. Capital Adequacy Ratio (CAR), adalah rasio permodalan yang menunjukkan kemampuan dalam menyediakan dana untuk keperluan pengembangan usaha serta menampung kemungkinan resiko kerugian yang diakibatkan dalam kegiatan operasional. Semakin tinggi nilai CAR maka bank tersebut mampu membayai kegiatan operasional dan kontribusi yang cukup besar bagi profitbilitas.

$$
\mathrm{CAR}=\frac{\text { Total Modal Bank } \times 100 \%}{\text { Aktiva tertimbang menurut resiko (ATMR) }}
$$

b. Debt to Equity Ratio (Rasio Hutang terhadap Ekuitas), adalah untuk mengukur kemampuan bank untuk menutup sebagian atau seluruh hutang-hutangnya dengan dana yng berasal modal sendiri. Rasio ini Perbandingan antara hutang - hutang dan ekuitas dalam pendanaan perusahaan dan menunjukkan kemampuan modal sendiri, perusahaan untuk memenuhi seluruh kewajibanya.

RUMUS:

$$
\text { Debt to equity ratio }(\mathrm{DTE})=\frac{\text { total hutang }}{\text { modal sendiri }} \times 100 \%
$$

Rasio ini menunjukkan hubungan antara jumlah hutang jangka panjang dengan jumlah modal sendiri yang diberikan oleh pemilik perusahaan, guna mengetahui jumlah dana yang disediakan kreditor dengan pemilik perusahaan.

\section{Rasio Rentabilitas atau Profitabilitas}

Rasio rentabilitas bertujuan untuk mengetahui kemampuan bank dalam menghasilkan laba selama periode tertentu. Rasio ini juga bertujuan untuk mengukur tingkat efektifitas manajemen dalam menjalankan operasional perusahaannya. Rasio rentabilitas (keuntungan), Dapat diukur dengan return on assets (ROA), return on equity (ROE), dan biaya operasional/pendapatan operasional. 
1) Return On Assets (ROA) adalah Rasio yang mengukurkemampuan bank didalam memperoleh laba dan efisiensi secara keseluruhan.ROA menunjukkan kemampuan manajemen bank dalam menghasilkan income dari pengelolaan aset yang dimiliki.Profitabilitas berkaitan dengan return dan risiko yang dihadapi oleh bank. Analisisprofitabilitas suatu bank adalah untuk mengukur tingkat efisiensi usaha danprofitabilitas yang dicapai oleh bank yang bersangkutan.

$$
\mathrm{ROA}=\frac{\text { laba sebelum pajak }}{\text { total aktiva }} \times 100 \%
$$

2) Return on Equity (ROE) menunjukkan kemampuan manajemen bank dalam mengelola modal yang tersedia untukmendapatkan net income. Semakin tinggi return semakin baik karena berartidividen yang dibagikan atau ditanamkan kembali sebagai retained earning jugaakan semakin besar. ROE dihitung dengan membandingkan antara Net Incomedengan Total Equity.Untuk mendapatkan ROE juga dapatdilakukan dengan menghubungkan ROA dengan Equity Multiplier (EM).

Rumus:

$\mathrm{ROE}=\quad$ Laba sebelum pajak $\times 100 \%$

Total modal

Semain besar nilai ROE, semain besar pula tingkat keuntungan yang dicapai bank sehingga kemungkinan kecil suatu bank dalam kondisi bermasalah.

3) Biaya Operasional/Pendapatan Operasional (BO/PO); Rasio ini digunakan untukmengukur perbandingan biaya operasi/biaya intermediasi terhadap pendapatanoperasi yang diperoleh bank. Semakin kecil angka rasio BO/PO, maka semakinbaik kondisi bank tersebut.

$\mathrm{BOPO}=\frac{\text { Biaya Operasional } \times 100 \%}{\text { Pendapatan Operasional }}$

\section{KERANGKA ANALISIS}

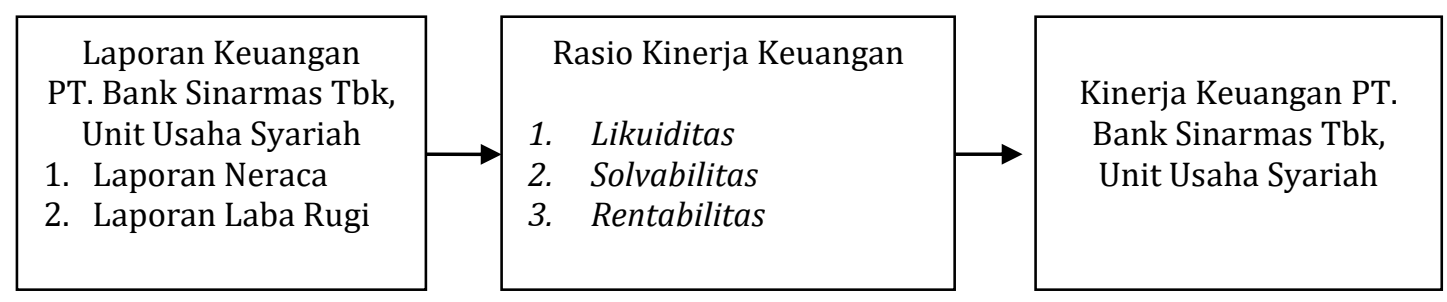

Gambar 1. Kerangka Analisis

\section{METODOLOGI}

Penelitian ini juga akan melakukan analisis kuantitatif dengan melakukan perbandingan rasio keuangan yang merupakan ukuran kinerja keuangan PT. Bank Sinarmas Tbk, Unit Usaha Syariah.

Metode yang digunakan untuk mengumpulkan data dalam pelaksanaan penelitian ini adalahmetode dokumentasi yaitu pengumpulan data dengan melihat dan mengamati data atau dokumen yang berkaitan dengan masalah yang di teliti berupa laporan keuangan neraca dan laba rugi PT. Bank Sinarmas Tbk, Unit Usaha Syariah tahun 2014-2016.

\section{HASIL PENELITIAN DAN PEMBAHASAN}

\section{RASIO LIKUIDITAS}

Suatu bank dikatakan liquid apabila bank yang bersangkutan dapat memenuhi kewajiban utangutangnya, dapat membayar kembali semua depositonya, serta dapat memenuhi permintaan kredit yang diajukan tanpa terjadi penangguhan. Oleh karena itu, bank dapat dikatakan liquid apabila:

1) bank tersebut memiliki cash assets sebesar kebutuhan yang digunakan untuk memenuhi likuiditasnya

2) bank tersebut memiliki cash assets yang lebih kecil dari kebutuhan likuiditasnya, tetapi mempunyai aset atau aktiva lainnya (misal surat berharga) yang dapat dicairkan sewaktu-waktu tanpa mengalami penurunan nilai pasarnya, dan

3) bank tersebut mempunyai kemampuan untuk menciptakan cash asset baru melalui berbagai bentuk hutang (Kasmir, 2009).Dalam rasio likuiditas, rasio yang dapat diukur antara lain: Cash Ratio (CR) dan Loan Deposit Ratio (LDR). 
a. Cash Ratio/Quick Ratio, yaitu Rasio ini untuk mengetahui kemampuan bank dalam membayar ke menggunakan alat likud dimilikinya.

$$
\mathrm{CR}=\frac{\text { Aktiva Likuid x }}{\text { Hutang Lancar }}
$$

Aktiva likuid adalah aktiva yang hanya dipakai satu atau beberapa kali dalam proses produksi dan mempunyai umur eonomisnya pendek (kurang dari satu tahun) dan paling mudah diubah menjadi uang. Aktiva likuid bank diperoleh dengan menjumlahkan kas, penempatan pada bank lain, sertifikat wadiah bank indonesia, surat berharga yang dimiliki pada sisi aktiva pada laporan neraca. Sedangkan hutang lancar diperoleh dari menjumlahkan kewajiban segera dan tabungan wadiah yang dimiliki bank pada sisi pasiva laporan neraca.

Tabel 1. Akiva likuid dan hutang lancar PT. Bank Sinarmas Tbk, Unit Usaha Syariah Tahun 2014-2016

\begin{tabular}{|c|c|c|c|c|}
\hline No. & Keterangan & 2014 & 2015 & 2016 \\
\hline \multicolumn{5}{|c|}{ Aktiva Likuid } \\
\hline 1 & Kas & 54.490 & 68.718 & 63.790 \\
\hline 2 & penempatan pada bank indonesia & 165.777 & 373.922 & 575.755 \\
\hline 3 & sertifikat wadiah pada bank indonesia & 13.100 & 216.000 & - \\
\hline 4 & penempatan pada lain & - & 260.000 & 90.000 \\
\hline 5 & PPAP penempatan pada bank lain & - & - & - \\
\hline 6 & surat berharga yang dimilki & 281.269 & 201.540 & 205.851 \\
\hline 7 & PPAP surat berharga yang dimilki & $(839)$ & - & - \\
\hline 8 & pendapatan yang masih akan diterima & 2.606 & 370 & - \\
\hline \multirow[t]{2}{*}{9} & biaya dibayar dimuka & 82.889 & 33.420 & - \\
\hline & Total aktiva Likuid & 599.292 & 1.153 .970 & 935.396 \\
\hline \multicolumn{5}{|c|}{ Hutang Lancar } \\
\hline 1 & dana simpanan wadiah & 116.815 & 203103 & 258745 \\
\hline 2 & liabilitas segera lainnya & 7.845 & - & - \\
\hline \multirow[t]{2}{*}{3} & Liabilitas lain-lain & 1.135 .123 & 322.138 & 40.860 \\
\hline & Total Hutang Lancar & 1.259 .783 & 525.241 & 299.605 \\
\hline
\end{tabular}
(Dalam Jutaan Rupiah)

Sumber: Hasil Perhitungan Data Diolah, 2017

Cash ratio merupakan alat untuk mengetahui kemampuan sebuah perbankkan dalam membayar kewajibannya kepada para nasabah yang menyimpan dananya dengan aktiva lancar yang di milikinya. Semakin tinggi rasio ini maka semakin tinggi tingkat likuiditasnya dan semakin baik pula kinerja perusahaan tersebut. Nilai cash ratio PT. bank sinarmas Tbk, unit syariah periode 2014, 2015, dan 2016 masing-masing adalah 47,57\%, 219,70\%, dan 312,21\%. Pada tahun 2014 PT. bank sinarmas Tbk, unit syariah mempunyai nilai cash ratio dibawah $75 \%$ sedangkan di tahun 2015 DAN 2016 diatas 75\%. Hal ini menunjukkan bahwa PT. Bank Sinarmas Tbk, Unit Syariah memiliki kinerja yang sangat baik setiap tahunnya selalu meningkat.

\section{b. Loan to deposit ratio}

Loan to deposito ratio merupakan alat untuk mengukur komposisi kredit yang diberikan dibandingkan dengan jumlah dana masyarkat/ deposito dan modal.

$$
\text { LDR }=\frac{\text { total kredit } \quad \times 100 \%}{\text { Total deposito }+ \text { modal }}
$$

Jumlah kredit diperoleh dengan menjumlahkan total piutang murabahah dan pembiyaan mudharabah dan musyarakah yang terdapat diposisi aktiva dalam laporan neraca. Jumlah deposito diperoleh dengan menjumlahkan tabungan wadiah, tabungan mudaharabah, dan deposito mudharabah yang terdapat pada posisi pasiva laporan neraca, sedangkan modal diperoleh dengan menjumlahkan dana usaha dan saldo laba (rugi) pada posisi pasiva laporan neraca. Perhitungan total kredit, total deposito, dan total modal PT. Bank Sinarams Tbk, Unit Syariah tahun 2014-2016 dapat dilihat pada table 2. Sebagai berikut: 
Tabel 2. Total Kredit, Deposito, Dan Modal PT. Bank Sinarmas Tbk, Unit Usaha Syariah (Dalam Jutaan Rupiah)

\begin{tabular}{|c|c|c|c|c|}
\hline No & Keterangan & 2014 & 2015 & 2016 \\
\hline \multicolumn{5}{|c|}{ Kredit } \\
\hline 1 & Piutang murabahah & 2.723 .300 & 644.083 & - \\
\hline 2 & PPAP piutang murabahah & $(31.949)$ & $(8.129)$ & - \\
\hline 3 & piutang lainnya & 671.805 & 79.618 & - \\
\hline 4 & PPAP piutang lainnya & $(10.789)$ & $(17.365)$ & - \\
\hline 5 & Pembiayaan muarabahah dan musyarakah & 2.938 .652 & 1.073 .091 & - \\
\hline 6 & PPAP pembiayaan & $(53.413)$ & $(16.942)$ & - \\
\hline \multirow[t]{2}{*}{7} & pembiayaan berbasis piutang & - & 2.296 .121 & 1.570 .713 \\
\hline & Total kredit & 6.237 .606 & 4.050 .477 & 1.570 .713 \\
\hline \multicolumn{5}{|c|}{ Deposito } \\
\hline 1 & Dana Simpanan Wadiah & 238.874 & 203.103 & 258.745 \\
\hline 2 & Tabungan Mudharabah & 491.627 & 340.742 & - \\
\hline \multirow[t]{2}{*}{3} & Deposito Mudharabah & 3.161 .984 & 1.432 .876 & \\
\hline & Total Deposito & 3.892 .485 & 1.976 .721 & 258.745 \\
\hline \multicolumn{5}{|c|}{ Modal } \\
\hline 1 & Modal / Dana usaha & - & 1.812 .048 & 1.322 .211 \\
\hline 2 & Tambahan Modal Disetor & - & - & - \\
\hline 3 & Dana investasi tidak terikat & 3.653 .611 & 1.773 .618 & 7.478 .430 \\
\hline 4 & Saldo Laba (Rugi)/ aba ditahan & 134.099 & 6.894 & 145.389 \\
\hline & Total Modal & 3.787 .710 & 3.592 .560 & 8.946 .030 \\
\hline
\end{tabular}

Sumber: Hasil Perolehan Data Diolah, 2017

LDR merupakan rasio yang digunakan untuk mengukur kemampuan bank dalam memenuhi permintaan para debitur dengan modal yang tersedia.berdasarkanvhasil perhitungan dapat dilihat nilai LDR yang dihasilkan PT. Bank Sinarmas Tbk, Unit Usaha Syariah periode 2014, 2015, dan 2016 menunjukkan bahwa PT. Bank Sinarmas Tbk, Unit Syariah memiliki kinerja keuangan yang tidak stabil disetiap tahunnya. Nilai LDR PT. Bank Sinarmas Tbk, Unit Syariah periode 2014-2016 masing-masingnya adalah 81,22\%, 72,73\%, dan 17,06\%.

Pada tahun 2014 dan 2016 PT. Bank Sinarmas Tbk, Unit Syariah memiliki jumlah kredit yang lebih tinggi jika dibandingkan dengan total modal dan pada tahun 2015 total kredit lebih rendah dibandingkan dengan modal maupun deposito yang dimmiliki bank.

\section{RASIO SOLVABILITAS}

Analisis solvabilitas digunakan untuk mengukur kemampuan bank untuk memenuhi kewajibankewajiban jika terjadi likuidasi bank. Rasio solvabiitas dapat diukur dengan perhitungan capital adequacy ratio (CAR) dan Debt To Equity Ratio.

a. Capital Adequacy Ratio (CAR), adalah rasio permodalan yang menunjukkan kemampuan dalam menyediakan dana untuk keperluan pengembangan usaha serta menampung kemungkinan resiko kerugian yang diakibatkan dalam kegiatan operasional. Semakin tinggi nilai CAR maka bank tersebut mampu membayai kegiatan operasional dan kontribusi yang cukup besar bagi profitabilitas.

\section{$\mathrm{CAR}=\quad$ Total Modal Bank x 100\% Aktiva tertimbang menurut resiko (ATMR)}

Aktiva tertimbang menurut resiko dihitung berdasarkan bobot persentase dari masingmasing komponen akun aktiva tertimbang menurut resiko. Adapun hasil perhitungan aktiva tertimbang menurut resiko dan total modal PT. Bank Sinarmas Tbk, Unit Syariah tahun 2014-2016 dapat dilihat pada table 3. Dan table 4. Sebagai berikut: 
Tabel 3. Daftar Akun Aktiva Tertimbang Menurut Resiko (ATMR) PT. Bank Sinarmas tbk, Unit Usaha Syariah Tahun 2014-2016 (dalam jutaan rupiah)

\begin{tabular}{|c|c|c|c|c|c|}
\hline No & Keterangan & 2014 & 2015 & 2016 & $\begin{array}{c}\text { Bobot } \\
\%\end{array}$ \\
\hline \multicolumn{6}{|c|}{ ATMR } \\
\hline 1 & Kas & 54,490 & 68,718 & 63,790 & $0 \%$ \\
\hline 2 & Penempa\&an pada Bank Indonesia & 165,777 & 373,922 & 575,75 & $0 \%$ \\
\hline 3 & Penempatan pada bank lain & - & 260,000 & 90,000 & $20 \%$ \\
\hline 4 & PPAP Penempatan bank lain & - & - & & $0 \%$ \\
\hline 5 & Surat ber任arga yang dimiliki & 281,269 & 201,540 & 205,81 & $0 \%$ \\
\hline 6 & PPAP Surat berharga yang dimiliki & (839) & - & - & $0 \%$ \\
\hline 7 & Sertifikat wadiah bank Indonesia & 13,100 & 216,000 & - & $0 \%$ \\
\hline \multirow[t]{2}{*}{8} & piutang murabaha & $2,723,300$ & 644,083 & - & $85 \%$ \\
\hline & Piutang lainnya & 671,805 & 79,618 & - & $85 \%$ \\
\hline 9 & Aset tetap dan inventaris & 157,432 & 157,052 & 136,31 & $100 \%$ \\
\hline 10 & Akumulaşi Penyusutan Aktiva Tetap -/- & $(21,892)$ & - & 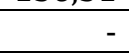 & $100 \%$ \\
\hline 11 & Aset lainnya & 7,295 & 167,724 & 237,12 & $100 \%$ \\
\hline
\end{tabular}

Tabel 4. Perhitungan ATMR dan Total Modal PT. Bank Sinarmas Tbk, Unit Usaha Syariah Tahun 2014-2016 (Dalam Jutaan Rupiah)

\begin{tabular}{|c|c|c|c|c|}
\hline No & Keterangan & 2014 & 2015 & 2016 \\
\hline \multicolumn{5}{|c|}{ ATMR } \\
\hline 1 & Kas & & - & - \\
\hline 2 & Penempatan pada Bank Indonesia & - & - & - \\
\hline 3 & Penempatan pada bank lain & - & 52.000 & 18.000 \\
\hline 4 & PPAP Penempatan bank lain & - & - & - \\
\hline 5 & Surat berharga yang dimiliki & - & - & - \\
\hline 6 & PPAP Surat berharga yang dimiliki & - & - & - \\
\hline 6 & Sertifikat wadiah bank indonesia & - & - & - \\
\hline 8 & piutang murabaha & 2.314 .805 & $547.470,55$ & - \\
\hline 9 & Piutang lainnya & $571.034,25$ & $67.675,30$ & - \\
\hline 10 & Aset tetap dan inventaris & 157.432 & 157.052 & 136.371 \\
\hline 11 & Akumulasi Penyusutan Aktiva Tetap -/- & $(21.892)$ & - & - \\
\hline \multirow[t]{2}{*}{12} & Aset lainnya & 7.295 & 167.724 & 237.142 \\
\hline & TOTAL ATMR & 3.028 .674 & 991.922 & 391.513 \\
\hline \multicolumn{5}{|c|}{ Modal } \\
\hline 1 & Modal / Dana usaha & - & 1.812 .048 & 1.322 .211 \\
\hline 2 & Tambahan Modal Disetor & - & - & - \\
\hline 3 & Dana investasi tidak terikat & 3.653 .611 & 1.773 .618 & 7.478 .430 \\
\hline \multirow[t]{2}{*}{4} & Saldo Laba (Rugi) & 134.099 & 6.894 & 145.389 \\
\hline & TOTAL MODAL & 3.787 .710 & 3.592 .560 & 8.946 .030 \\
\hline
\end{tabular}

Perhitungan rasio solvabilitas (CAR) pada PT. Bank Sinarmas Tbk, Unit Usaha Syariah

CAR $=$ Total Modal Bank $\times 100 \%$

Aktiva tertimbang menurut resiko (ATMR)

Nilai rasio pada PT. Bank Sinarmas Tbk, unit usaha syariah tahun 2014-2016 menunjukkan angka diatas 8\%, masing-masing nilai adalah 125,06\%, 362,18\%, dan 2.285\%. Standar rasio kecukupan yang ditetapkan oleh bank Indonesia untuk perbankkan minimal adalah 8\%. Nilai rasio yang dihasilkan PT. Bank Sinarmas Tbk, Unit Usaha Syariah tahun2014-2016 menunjukkan banhwa PT. Bank Sinarmas Tbk, Unit Usaha Syariah mempunyai kecupan modal untuk menutupi resiko kredit macet yang ada sehingga perusahaan masih mampu memenuhi kewajiban kepada nasabahnya masih akan terpenuhi.

b. Debt to Equity Ratio (Rasio Hutang terhadap Ekuitas), adalah untuk mengukur kemampuan bank untuk menutup sebagian atau seluruh hutang-hutangnya dengan dana yng berasal modal sendiri. Rasio ini Perbandingan antara hutang - hutang dan ekuitas dalam pendanaan perusahaan dan menunjukkan kemampuan modal sendiri, perusahaan untuk memenuhi seluruh kewajibanya. 
Tabel 5. Hutang dan modal PT. Bank Sinarmas Tbk, Unit Usaha Syariah Tahun 2014-2016

\begin{tabular}{|c|c|c|c|}
\hline HUTANG & 2014 & 2015 & 2016 \\
\hline 1. Dana Simpanan Wadiah & 238.874 & 203.103 & 258.745 \\
\hline 2. Kewajiban Segera Lainnya & 13.848 & - & - \\
\hline 3. Kewajiban Kepada Bank Indonesia & - & - & - \\
\hline 4. Kewajiban Kepada Bank Lain & 440.895 & 546.807 & 853.363 \\
\hline 5. Surat Berharga Yang Diterbitkan & - & - & - \\
\hline 6. Kewajiban Lain-lain & 2.498 .406 & 322.138 & 40.860 \\
\hline TOTAL HUTANG & 3.192 .023 & 1.072 .048 & 1.152 .968 \\
\hline & & & Modal \\
\hline 1. Modal / Dana usaha & - & 1.812 .048 & 1.322 .211 \\
\hline 2. Tambahan Modal Disetor & - & - & - \\
\hline c. Dana investasi tidak terikat & 3.653 .611 & 1.773 .618 & 7.478 .430 \\
\hline 3. Saldo Laba (Rugi)/Laba ditahan & 134.099 & 6.894 & 145.389 \\
\hline TOTAL MODAL & 3.787 .710 & 3.592 .560 & 8.946 .030 \\
\hline
\end{tabular}

Debt to equity ratio $=\frac{\text { Total Hutang } \times 100 \%}{\text { Modal }}$

Debt to equity ratio tahun 2014-2016 menunjukkan nilai masing masing 84,27 \%, 29,84 \% dan 12,88\%. Rasio ini menunjukkan hubungan antara jumlah hutang jangka panjang dan jangka pendek dengan jumlah modal sendiri diberikan oleh pemilik perusahaan, guna mengetahui jumlah dana yang disediakan kreditor dengan pemilik perusahaan.

\section{RASIO RANTABILITAS}

Rasio rentabilitas/profitabilitas menunjukkan kemampuan perusahaan untuk menghasilkan laba selama perode tertentu,rentabiilitas dapat diukur dengan perhitungan biaya operasional terhadap pendapatan operasional (BOPO), Return On Aseet (ROA), Return On Equity (ROE).

1. Biaya Operasional/Pendapatan Operasional (BO/PO)

Rasio ini digunakan untuk mengukur perbandingan biaya operasi/biaya intermediasi terhadap pendapatan operasi yang diperoleh bank. Semakin kecil angka rasio BO/PO, maka semakin baik kondisi bank tersebut.

$$
\text { BOPO }=\underset{\text { biaya operasioanal } \times 100 \%}{\text { Pendapatan operasional }}
$$

Beban operasional PT. Bank Sinarmas Tbk, Unit Usaha Syariah tahun 2014 sangatlah tidak baik, dapat dilihat nilai rasio BOPO menunjukkan angka diatas 93,52\% dan pada tahun 2015 dan 2016 menunjukkan angka dibawah 93,52\%. Nilai rasio BOPO PT. Bank Sinarmas Tbk, Unit Usaha Syariah tahun 2014, 2015, dan 2016 masing-masing adalah 169,20\%, 37,17\%, dan 27,25\%. Jika dilihat dari rasio BOPO kinerja keuangan p ada PT. Bank Sinarmas Tbk, Unit Usaha Syariah tahun2014 sangatla tidak baik namun sangatla baik untuk di tahun 2015 dan 2016 sangat meningkat baik dari tahun 2014.

2. Return On Assets (ROA)

ROA menunjukkan kemampuan manajemen bank dalam menghasilkan income dari pengelolaan aset yang dimiliki.

$$
\text { ROA }=\frac{\text { Laba sebelum pajak } \quad \mathrm{x} 100 \%}{\text { Total aktiva }}
$$

Nilai ROA PT. Bank Sinarmas Tbk, Unit Usaha Syariah tahun 2014, 2015, dan 2016 masing-masing adalah 1,31\%, 0,10\%, dan 1,64\%. Hal ini menunjukkan bahwa PT. Bank Sinarmas Tbk, Unit Usaha Syariah pada tahun 2015 sangatla buruk dibandingan tahun sebelum dan setelahnya.

3. Return on Equity (ROE) menunjukkan kemampuan manajemen bank dalam mengelola modal yang tersedia untuk mendapatkan net income. ROE dihitung dengan membandingkan antara Net Income dengan Total Equity. Untuk mendapatkan ROE juga dapat dilakukan dengan menghubungkan ROA dengan Equity Multiplier (EM).

$$
\text { ROE }=\frac{\text { Laba sebelum pajak } \times 100 \%}{\text { Total modal }}
$$


Semakin besar nilai ROE, semain besar pula tingkat keuntungan yang dicapai bank sehingga kemungkinan kecil suatu bank dalam kondisi bermasalah. Masing-masing nilai ROE adalah 2,41\%, 0,26\%, dan 1,85\%. Hal ini menunjukkan bahwa PT. Bank Sinarmas Tbk, Unit Usaha Syariah ditahun 2014 dikategorikan sangat baik Sedangkan Tahun 2015 dan 2016 dikategorikan sangat buruk.

\section{ANALISIS RASIO}

Berdasarkan hasil analisi rasio keuangan pada PT. Bank Sinarmas Tbk, Unit Usaha Syariah tahun2014-2016, maka hasil penilaian terhadap hasil kinerja keuangan PT. Bank Sinarmas Tbk Unit Usaha Syariah dapat dilihat pada table berikut:

Tabel 6. Rasio keuangan PT. Bank Sinarmas Tbk, Unit Usaha Syariah Tahun 2014-2016

\begin{tabular}{|c|c|c|c|c|c|c|c|}
\hline No. & Keterangan & 2014 & Kategori & 2015 & Kategaori & 2016 & Kategori \\
\hline \multicolumn{8}{|c|}{ Likuiditas } \\
\hline 1 & Cash Ratio & $47,57 \%$ & Cukup baik & $219,70 \%$ & baik & $312,21 \%$ & Baik \\
\hline 2 & LDR & $81,22 \%$ & Cukup baik & $72,73 \%$ & baik & $17,06 \%$ & Baik \\
\hline \multicolumn{8}{|c|}{ Solvabilitas } \\
\hline 1 & CAR & $125,06 \%$ & baik & $362,18 \%$ & baik & $2.285 \%$ & Baik \\
\hline 2 & Debt to Equity Ratio & $84,27 \%$ & Cukup baik & $29,84 \%$ & baik & $12,88 \%$ & Baik \\
\hline \multicolumn{8}{|c|}{ Rentabilitas } \\
\hline 1 & BOPO & $65,83 \%$ & baik & $109,21 \%$ & Tidak baik & $155,49 \%$ & Tidak baik \\
\hline 2 & $\mathrm{ROA}$ & $1,31 \%$ & Cukup baik & $0,10 \%$ & Tidak baik & $1,64 \%$ & Baik \\
\hline 3 & ROE & $2,41 \%$ & Tidak baik & $0,26 \%$ & Tidak baik & $1,85 \%$ & Tidak baik \\
\hline
\end{tabular}

Sumber: Hasil Perolehan Data Diolah, 2017

Berdasarkan tabel 6. diatas, kinerja keuangan PT. Bank Sinarmas Tbk Unit Usaha Syariah tahun 2014-2016 dapat dijabarkan sebagai berikut:

1. Rasio likuiditas

PT. Bank Sinarmas Tbk Unit Syariah memiliki kinerja keuangan dilihat dari cash ratio dikategorikan cukup baik pada tahun 2014 sedangkan tahun 2015-2016 dikategorikan sangat baik jika hasil cash ratio-nya diatas 75\% yang lebih besar dari pada ketetapan yang berlaku. Hal ini menujukkan bahwa perusahaan mampu membayar semua kewajiban lancarnya dengan menggunakan aktiva likuid yang dimilikinya sehingga perbankan dapat meminimalisir resiko kekurangan dana.

Jika dilihat dari rasio LDR, PT. Bank Sinarmas Tbk Unit Syariah pada tahun 2014 dikategorikan cukup baik sedangkan tahun 2015-2016 dikategorikan baik karena memiliki kinerja keuangan yang nilai rasio LDR dibawah $75 \%$.

2. Rasio solvabilitas

PT. Bank Sinarmas Tbk Unit Syariah jika dilihat dari nilai CAR pada tahun 2014-2016 memiliki kinerja keuangan yang baik, nilai CAR yang diperoleh adalah sebesar 125,06\%, 362,18\% dan 2.285\%. PT. Bank Sinarmas Tbk Unit Syariah sudah mencapai nilai minimum yang telah ditetapakn oleh Bank Indonesia, dimana kecupan modal minimum adalah $8 \%$.

Jika dilihat dari debt to equity ratio padatahun 2014 dikategorikan baik dan cukup baik dimana nilai rasio nya dibawah $100 \%$. Nilai rasio debt to equity ratio PT. Bank Sinarmas Tbk Unit Syariah masingmaing adalah 84,27\%, 29,84\%, dan 12,88\%.

3. Rasio Rentabilitas

PT. Bank Sinarmas Tbk Unit Syariah memiliki kinerja keuangan yang tidak stabil karena setiap tahun naik turun, bisa dilihat dari hasil perhitungan rasio BOPO, ROA, dan ROE masing-masing nilai adalah BOPO (65,83\%, 109,21\%, dan 155,49\%), ROA (1,31\%, 0,10\%, dan 1,64\%), dan ROE $(2,41 \%, 0,26 \%$, dan $1,85 \%)$.

\section{KESIMPULAN}

1. Dilihat dari Cash Ratio (CR) tahun 2014 dikateorikan cukup baik sedangkan tahun 2015 dan 2016 pada PT. Bank Sinarmas Tbk, Unit Usaha Syariah dikategorikan baik

2. Dilihat dari Loan to Deposit (LDR) PT. Bank Sinarmas Tbk, Unit Usaha Syariah tahun 2014 dikategorikan cukup baik, tahun 2015 dan 2016 dikategorikan baik.

3. Dilihat dari Capital Adequacy Ratio (CAR) PT. Bank Sinarmas Tbk, Unit Usaha Syariah tahun 2014 dan 2016 dikategorikan baik. 
4. Dilihat dari Debt To Equity Ratio PT. Bank Sinarmas Tbk, Unit Usaha Syariah pada tahun 2014 dikategorikan cukup baik, sedangkan dari tahun 2015 dan 2016 kategorikan baik.

5. Dilihat dari rasio BOPO PT. Bank Sinarmas Tbk, Uni Usaha Syariah tahun 2014 dikategorikan baik karena PT. Bank Sinarmas Tbk, Unit Usaha Syariah memiliki pendapatan yang lebih besar dari pada beban operasional. 2015 dan 2016 dikategorikan tidak baik karena PT. Bank Sinarmas Tbk, Unit Usaha Syariah memiliki beban operasional lebih besar daripada pendapatan operasional yang diterima, sedangkan ditahun

6. Dilihat dari Return On Asset (ROA) tahun 2014 PT. Bank Sinarmas Tbk, Unit Usaha Syariah dikategorikan cukup baik, ditahun 2015 PT. Bank Sinarmas Tbk, Unit Usaha Syariah justru dikatakan tidak baik karena pendapatan yang diterima tidak mencukupi hanya dengan memanfaatkan asset saja, sedangkan tahun 2016 PT. Bank Sinarmas Tbk, Unit Usaha Syariah dikategorikan baik.

7. Dilihat dari Return On Equity (ROE) tahun 2014 dan 2016 PT. Bank Sinarmas Tbk, Unit Usaha Syariah dikategorikan tidak baik karena pendapatan yang diterima tidak mencukupi dengan hanya memanfaatkan modal saja.

8. PT. Bank Sinarmas Tbk, Unit Usaha Syariah pada tahun 2014-2016 mempunyai kinerja keuangan yang baik dari rasio likuiditas, rasio solvabilitas, dan rasio rentablitas. Meskipun jika dilihat dari rasio rentabilitas BOPO tahun 2015 dan 2016, ROA tahun 2015 dan ROE tahun 2015-2016 PT. Bank Sinarmas Tbk, Unit Usaha Syariah dikategorikan tidak baik.

\section{SARAN}

1. PT. Bank Sinarmas Tbk, Unit Usaha Syariah perlu meningkatkan modal dan jumlah deposito agar perbankan dapat memenuhi permintaan kredit dari masyarakat dan tidak mengalami kekurangan dana.

2. PT. Bank Sinarmas Tbk, Unit Usaha Syariah perlu mengevaluasi kembali hutang-hutang perbankan yang sudah ada tidak melebihi modal yang dimiliki.

3. PT. Bank Sinarmas Tbk, Unit Usaha Syariah untuk menekan biaya operasional yang dikeluarkan agar lebih efisien sehingga laba yang dihasilkan lebih optimal.

\section{DAFTAR PUSTAKA}

Arthesa Ade dan Handiman Edia. 2006. Bank dan Lembaga Keuangan Bukan Bank. Jakarta : PT INDEKS Kelompok Gramedia.

Bank Indonesia, Peraturan Bank Indonesia Nomor 13/1/PBI/2011 tanggal 05 Januari 2011. Perihal Tatacara Penilaian Tingkat Kesehatan Bank Umum.

Bank Indonesia, Peraturan Bank Indonesia Nomor 6/10/PBI/2004. Perihal Sistem Penilaian Tingkat Kesehatan Bank Umum.

Bank Indonesia, Laporan Keuangan Publikasi triwulan. http://www.bi.go.id. /web/id

Bank Indonesia. Peraturan Bank Indonesia Nomor: 13/27/PBI/2011 tanggal 28 Desember 2011 Tentang Perubahan Atas Peraturan Bank Indonesia No.11/1/PBI/2009 Tentang Bank Umum.

Budisantoso, Totok dan Sigit Triandaru. 2006. Bank dan Lembaga Keuangan Lain. Jakarta : Salemba Empat.Bank Indonesia,1992, UU No. 7 tahun 1992, tentang Perbankan, Jakarta.

Hasibuan, Malayu S.P. 2001. Dasar-Dasar Perbankan. PT. Bumi Aksara, Jakarta.

Jayanti, mandasari. Analisis kinerja keuangan dengan pendekatan metode rgec pada bak BUMN (studi kasus bank BRI, BNI, BTN, Mandiri periode 2012-2013)

Subramanyam (2014:4), Analisis laporan keuangan (financial statement analysis) adalah aplikasi dari alat dan teknik analitis untuk laporan keuangan bertujuan umum dan data-data yang berkaitan untuk menghasilkan estimasi dan kesimpulan yang bermanfaat dalam analisis bisnis.

Sumarti. 2007. Analisis Kinerja Keuangan Dengan Menggunakan Metode Camel (Studi Kasus Bank Syariah Mandiri Tahun 2004-2006). Skripsi. Jakarta. Universitas Muhammadiyah Surakarta

Kasmir, Bank dan Lembaga Keuangan Lainnya, Fajar Interpratama Offset, Jakarta, Mei 2012

Kasmir. S.E.,M.M. 2012. Analisis Laporan Keuangan. Jakarta. PT. Rajawali Grafindo Persada.

Kasmir (2012:12), Manajemen Perbankan. Edisi Revisi. Penerbit PT. Raja Pers. Jakarta.

Santoso, Gempur, Drs. 2005. Metodologi Penelitian Kuantitatif \& Kualitatif. Prestasi Pustaka, Jakarta. Waworuntu, Bob. 1997. Dasar-Dasar Keterampilan Melayani Nasabah Bank. Gramedia Pustaka, Jakarta. http//:www.banksinarmas.com. 